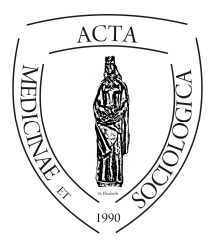

doi:

\title{
A digitális egyenlőtlenség vizsgálata a társadalmi kirekesztődés szempontjából
}

\author{
Huszti Elek \\ Drd. Babeş-Bolyai Tudományegyetem Kolozsvár Szociológia és Szociális Munkásképző Kar \\ Szociológia Doktori Iskola
}

\section{INFO ABSTRACT}

\begin{abstract}
Huszti Elek
husztielektarpa@gmail.com
\end{abstract}

\section{Keywords:}

poverty, social, digital, exclusion, multimedia, Bereg

\begin{abstract}
My research, which is part of a doctoral thesis, was made in Bereg the most backward subregion of Hungary in 2017. I examined the risk of poverty and social exclusion concerning the children of the age of 14 living here. I looked at this risk from a new angle, the angle of digital inequality. I looked for the answer whether the usage of the modern multi-media devices and the internet can help in the development of this subregion, the future generation will be able to meet the exigencies of the time, find a job in the digitalized labour market. Or else, the lack of these devices and the disability of using them make their position worse. I unveiled the students' sociodemographic, socioeconomical features, the degree of the supply concerning multi-media devices, the purpose of their usage, their attributes and the factors causing digital inequality. I scrutinized the degree of ICT usage at schools, the relationship between the usage of the internet and the school achievements, the students' relationships and their future prospects. In this article I would like to introduce the first part of my research in which I examined the socioeconomical background of the degree of supply with multimedia devices.
\end{abstract}

\footnotetext{
Kulcsszavak: szegénység, társadalmi, digitális, kirekesztődés, multimédia, Bereg
} Absztrakt: Kutatásomat, mely egy doktori tézis része, a

Absztrakt: Kutatásomat, mely egy doktori tézis része, a
Beregben, Magyarország egyik legelmaradottabb kistérsé-
gében végeztem, 2017-ben. Az itt élö 14 éves korosztály
szegénység és társadalmi kirekesztödés kockázatának mér-
tékét vizsgáltam. Mindezt a társadalmi egyenlőtlenség egy
új dimenziója a digitális egyenlötlenség aspektusábool
szemlélve. Arra a kérdésre kerestem a választ, hogy a mo-
dern multimédiás eszközök, valamint az internet használata
hozzájárulhat-e a kistérség fejlödéséhez, a jövő generációja
képes lesz-e megfelelni a kor kihívásainak, munkát találni
a digitalizációval átszőtt munkaeröpiacon. Esetleg ezen


eszközök, valamint a használatukhoz szükséges tudás hiánya tovább mélyíti-e a már meglévő társadalmi egyenlőtlenséget. Feltártam a tanulók szociodemográfiai, szocioökonómiai jellemzőit, multimédiás eszközökkel való ellátottságát, a használat céljait, attribútumait, a digitális egyenlőtlenséget okozó tényezőket. Kitértem az iskolai IKT használat szintjére, az internethasználat és a tanulmányi eredmények összefügéseire, a tanulók társas kapcsolatainak, jövőképének vizsgálatára. Jelen cikkemben kutatásom első kérdéskörét kívánom bemutatni, mely a multimédiás eszközökkel való ellátottság szocioökonómiai hátterének vizsgálatával foglalkozik.

\section{A tanulmány elméleti háttere}

Magyarországon, a társadalmi kirekesztődésre nézve, a legnagyobb kockázatot a munkaerőpiactól való távolmaradás jelenti, mely leginkább a munkahelyüket elvesztőket, a pályakezdőket, a szülési szabadságról, illetve távollétről visszatérőket és a rokkanttá váltakat érinti. Másik fontos tényező az alacsony iskolázottság, ugyanis az alapfokú végzettségü embereknek jóval nagyobb az esélye a munkanélküliségre. Nagymértékben ki vannak téve a szegénység kockázatának a 3 vagy több gyermeket nevelő családok, mivel a 18 év alatti gyermekek számának emelkedésével nő a szegénységi kockázat. Ugyanígy az egyszülős családok, akik gyermeküket egyedül nevelik, átlagon felül veszélyeztetettek. A roma származás háromszoros szegénységi kockázatot jelent, körükben tízszeres a tartós szegények aránya. Komoly rizikót jelent még a fentieken kívül a társadalomföldrajzi elhelyezkedés is (Európai Bizottság 2001; Spéder 2002, 2003; Fábián és Takács 2012).

A világháló használatának hiánya bekerült az Eurostat szegénységet és társadalmi kirekesztődést mérő tételei közé, ami mutatja, hogy a társadalmi egyenlőtlenségeknek egy új típusa alakult ki, mely a multimédiás eszközök birtoklásával, az internethasználatával függ össze. Ez pedig nem más, mint a digitális szakadék vagy egyenlőtlenség. Fogalma alapvetően az egyes társadalmi csoportok, informatikai eszközökhöz való, különböző mértékü hozzáférését jelenti. Az egyenlőtlenségek a társadalomkutatás jól ismert tényezői mentén jelentkeznek, mint a kor, az iskolai végzettség, az anyagi helyzet, a lakóhely vagy a földrajzi régió. Az elsődleges egyenlőtlenség az internethez való hozzáférést vizsgálja, míg a másodlagos egyenlőtlenség az internethasználati szokásokkal foglalkozik (Csepeli és Prazsák 2012). A másodlagos egyenlőtlenség DiMaggio-Hargittai szerzőpáros által meghatározott öt dimenziója a következő: technikai felszereltség, társadalmi támogatás, a hálózat autonómiájának egyenlőtlensége, az eszközhasználat, valamint a tudásbeli különbség mértéke. Kezdetektől fontos kérdés volt, hogy az infokommunikációs technológiák elterjedésével a deprivációt okozó tényezők meggyengülnek-e vagy az egyes csoportok között tovább mélyül a szakadék (Galácz és Ságvári 2008). 


\section{A kutatás módszertana}

Kutatásom szervesen illeszkedik a társadalomtudományok témakörébe, az innovatív és multimédiás eszközök társadalomra gyakorolt hatását vizsgálja a szegénység és társadalmi kirekesztődés tükrében.

Helyszíne a Beregi tájegység, mely Szabolcs-Szatmár-Bereg megye tiszaháti részén helyezkedik el, a Szatmár-Beregi-síkság része. Központja Vásárosnamény, mely a beregi falvakkal együtt alkotja 2004-től kezdve a Vásárosnaményi kistérséget. Ennek a kistérségnek a fejlődését számos tényező hátráltatja, a települések szerkezetén túl az ország keleti részében való elhelyezkedés, az országosnál lényegesen rosszabb foglalkoztatási helyzet, a romák magas aránya vagy a jelentős elvándorlás, mely inkább a képzettebb rétegeket érinti. Igaz, itt az országosnál kedvezőbb természetes szaporulatot találunk, de e mögött a jelenség mögött a magasabb termékenységgel bíró, képzetlenebb, szegényebb rétegek állnak.

Munkámat kvantitatív módszerrel végeztem. A kérdőíves felmérés 73 kérdést tartalmazott, 8 fejezetre osztva.

Az általam összeállított kérdőívet 280 diák töltötte ki. A Beregi-tájegység 27 településéből 12-ben müködik általános iskolai felső tagozat, 14 intézményben. A 8. osztályos tanulók vettek részt a kutatásban, azonban volt olyan intézmény, ahol a 7-8. évfolyam összevont osztályként müködött. Így került a mintába 16 fö 7 . osztályos tanuló, a 8. osztályosok létszáma 264 fő volt. A kutatási etikát betartottam. A kérdöív kitöltése önkéntes és teljesen anonim volt. Az adatok Excel táblázatban kerültek tárolásra.

A vizsgált mintában (n=280) 163 fö fiú (58\%) és 117 fö lány (42\%) volt. Életkoruk 12-17 év közötti, átlagban 14 év. 47-en városban, 233-an falun élnek. A tanulók nagy része (86,8\%) 3-6 fős családokban él, 81,8\% mindkét szülőjével együtt. Az egyszülős családokban élő gyerekek (14,7\%) többsége az édesanyjával él egy háztartásban (11,8\%). Magas a 3 vagy több gyermekes családok aránya (42,1\%), valamint a roma tanulóké (50,5\%). A vizsgált tanulók kisebb részének vannak diplomás szülei. A diplomás szülők között a nők vannak többségben 22,9\%-kal, míg a férfiak aránya $14,6 \%$. A gimnáziumot végzett szülők esetében is a nők dominanciája állapítható meg (nők 14,3\%, férfiak 9,3\%). Míg a férfiak 46,8 \%-a szakmunkásképzőt végzett, addig a nőknek csupán 27,5\%-a szerzett ilyen végzettséget. Az anyák egyharmadának általános iskolai végzettsége van (33,6\%), az apáknál alacsonyabb ez az arány (27,1\%).

A kérdőív adatainak feldolgozása és elemzése a Microsoft Excel táblázatkezelő és diagramkészítő program, valamint az SPSS statisztikai programcsomag alkalmazásával történt.

A kutatás hipotéziseinek tesztelésére többféle statisztikai módszert alkalmaztam. $\mathrm{Az}$ egyes változók egymáshoz való viszonyát, a Pearson-féle korreláció és a Spearman-féle rangkorreláció alkalmazásával, valamint varianciaanalízissel, kereszttábla és diszkriminancia elemzéssel teszteltem. A nemek, valamint a munkanélküli családtaggal rendelkezők és nem rendelkezők közötti különbségek kétmintás t próbával lettek vizsgálva. Létrehozásra került egy globális vulnerabilitás mutató, mellyel a társadalmi kirekesztődés kérdését vizsgáltam az egyes társadalmi 
csoportok sérülékenységén keresztül. Ehhez a mutatóhoz a szülök legmagasabb iskolai végzettségét vettem alapul, oly módon, hogy abban mindkét szülö végzettsége egyformán beleszámítson. A létrehozott mutató két logisztikus regressziós modell magyarázó változója lett.

Dolgozatomban a kérdőíves felmérés eredményeit a következő adatokkal vetettem össze:

- A 2011-es népszámlálás országos, megyei és járási adatai

- KSH (Központi Statisztikai Hivatal): A háztartások életszínvonala, 2016, 2017

- Magyar Ifjúság Kutatás. Szerk.: Székely Levente - Szabó Andrea. 2016

- NMHH (Nemzeti Média-és Hírközlési Hatóság): Lakossági internethasználat online piackutatás 2016, 2017

\section{A kutatás célja}

Kutatásomat három kérdéskör mentén csoportosítottam. Ezek közül az első a multimédiás eszközökkel való ellátottság szociodemográfiai és szocioökonómiai hátterével foglalkozott. Jelen cikkemben ennek a kérdéskörnek az eredményeit mutatom be.

A legtöbb magyar és nemzetközi vizsgálat arra enged következtetni, hogy a digitális eszközök és az internethasználat esetében a kor, a lakóhely és a jövedelem mellett a legjelentősebb diverzifikációs tényező az iskolai végzettség (pl.: Galácz és Ságvári 2008; Csepeli és Prazsák 2010), ezért fontosnak tartottam megvizsgálni, hogy a kutatásomba bevont települések esetében is igaz-e ez az állítás. Nem csak az iskolai végzettség és az eszközrendszerek kapcsolatát vizsgáltam, de feltételeztem, hogy ezek a használat változatosságára is pozitívan hatnak, akár transzgenerációs utakon is, egyrészt az eszközök nagyobb száma és változatossága révén, másrészt a magasabb iskolai végzettség szélesebb tájékozottsággal is járhat a digitális világ színterein.

Az iskolai végzettségen kívül a családok szocioökonómiai háttere is döntő tényező annak tekintetében, hogy kialakul-e a digitális szakadék valamilyen formája vagy sem (Csepeli és Prazsák 2010; Galgácz és Ságvári 2008). Ezért az iskolai végzettség mellett vizsgáltam a szocioökonómiai helyzet szerepét is az eszközök elérhetősége, és a használat változatosságának szempontjából.

A családon kívül a tágabb, de még lokális társadalmi környezet is erős tényezője lehet a szocializációs folyamatoknak. Vizsgálatomban abból a feltevésből indultam ki, hogy a lokális társadalom jellemzői serkentő és gátló hatással is lehetnek a gyermekek otthoni digitális környezetére és internethasználati szokásaira. Ez a hatásrendszer természetesen számtalan úton müködhet, mint a mintaadás/követés révén vagy pusztán azáltal a közvetett hatás által, hogy az adott környékre milyen jövedelmi viszonyok jellemzők. Az alacsony iskolai végzettség, a munkanélküliség és a bünözés különböző formái, mint a "problémás környék" összetevői, gyakran indikátorai az alacsony szocioökonómiai státusznak is (Bodonyi, Hegedüs és Fekete 2015), ami a multimédiás eszközhasználaton és az internet penetráción is nyomot hagy.

A nemzetközi és a hazai szakirodalom is talált példát a férfiak és nők eltérő multimédihasználati szokásaira. Több tanulmány is kimutatta például, a számítógé- 
pet és az internetet használók között a férfiak előnyét. (Hargitai 2003, Csepeli és Prazsák 2010). Kutatásomban ezért én is összehasonlítottam a két nem jellemzőit.

\section{A kérdőíves felmérés eredményei}

A Vásárosnaményi kistérség az Észak-alföldi régióban található, melynek lakói a legkevesebb, éves, átlagos bruttó jövedelemmel rendelkeznek az országban. Így nem meglepö, hogy a tanulók is igen alacsony jövedelmekről számoltak be.

A diákok többségének családjai nem rendelkeznek magas jövedelemmel, 200.000 Ft-os jövedelemből élő háztartásban csak 23,9\%-uk él, míg 5,6\%-uknak kevesebb, mint 100.000 Ft-ból kell boldogulnia. Ennek ellenére 90,3\%-uk átlagosnak vagy átlagon felülinek ítéli meg családja anyagi helyzetét. 15,71\%-ukra mondhatjuk, hogy az átlagosnál szegényebbnek érzi magát. A szülők többsége fizikai munkát végez (férfiak 56,1\%, nők 37,5\%). A nők körében a munkanélküliség magas, 16,43\%-os, a férfiak arányának (6,43\%) többszöröse. A tanulók 29,3\%-ának családjában volt munkanélküli az elmúlt egy évben. 25\%-uk érzi úgy, hogy mindene megvan, 50\%uk tapasztalja, hogy csak a mindennapi élethez legszükségesebb dolgok megvásárlását engedhetik meg maguknak, 12,1\%-uk számára pedig még ez is nehéz vagy egyenesen lehetetlen.

Kutatásomban a tanulók lakókörnyezetét is igyekeztem feltérképezni. Nagy többségük $(95,7 \%)$ saját tulajdonú ingatlanban, családi házban vagy lakásban lakik. A kistérségben találkozhatunk, különösen a cigánysorokon, szegregátumokban, kicsi alapterületü, komfort nélküli házakkal, ugyanakkor itt a legmagasabb az egy szobára jutó családtagok száma. Ennek tükrében nem meglepő, hogy a tanulók kicsivel több, mint ötöde (19,6\%) elégedetlen lakhatási körülményeivel.

Kérdőívemben kitértem annak vizsgálatára is, hogy a diákok milyen problémákkal kénytelenek szembenézni környezetükben. A „problémás környék” fogalmának használatát, vizsgálatát az tette szükségessé, hogy a kistérség a rendszerváltás óta eltelt időszakban nem a fejlődés, a hátrányok leküzdésének és a felzárkózásnak az irányába indult el, hanem elkezdődött a szegregátumok létrejötte, sőt beindult a gettósodás folyamata. Ez a kistérség 24 településéből 14-et érint (Balázs, Habarics és munkatársai 2012).

A tanulók válaszaiból és a kistérség védőnőinek véleményéből is az derült ki, hogy a legnagyobb problémát a tanulók környezetében a dohányzás és az alkoholfogyasztás jelenti. A cigarettázás 50,7\%-uk, az alkoholfogyasztás pedig 33,9\%-uk környezetében tapasztalható. A problémás környék rizikófaktorai közül az iskolai eredményességgel összefüggők a leghangsúlyosabbak. Sajnos a tanulók sok példát látnak az iskolai eredménytelenségre környezetükben, arra, hogy valaki a középiskola elvégzése után nem tanul tovább és nem is dolgozik, vagy be sem fejezi az elkezdett középiskolát, így nem szerez érettségit, vagy szakmát.

A tanulók számára fontos a multimédiás eszközök birtoklása, 81,4\%-uk szerint általuk előnybe kerülnek társaikkal szemben, 51,4\%-uk szerint velük boldogabb életet élhetnek, 47,5\%-uk szerint pedig sikeresebbek lehetnek. Minden 4. tanuló (26,1 \%) érezte már magát hátrányban ezen eszközök vagy az internethasználat hiá- 
nyából kifolyólag. A kutatás eredményeiből kitűnik, hogy a vizsgálatban résztvevő fiatalok multimédiás eszközökkel való ellátottsága az országos adatokkal való öszszevetés függvényében is jónak mondható. A legtöbb tanulónak (50,7 \%) 3-7 multimédiás eszköze van, de 30,5\%-uknak ennél is több, 8-14 eszköze, valamint vannak olyan tanulók is (2 fö) akik 20 db ilyen eszközt birtokolnak. Azok aránya, akik semmilyen multimédiás eszközzel nem rendelkeznek 1,4\% (4 fó). A tanulók 93,2\%a rendelkezik saját mobiltelefonnal, $90 \%$-uk okostelefonnal, 65,7\%-uk asztali számítógéppel 40,7 \%-uk laptoppal/notebookkal, 48,6 \%-uk táblagéppel, 47,9\%-uk plazma/LCD televízióval. A birtokolt multimédiás eszközök számának átlaga 6,9 eszköz/fö.

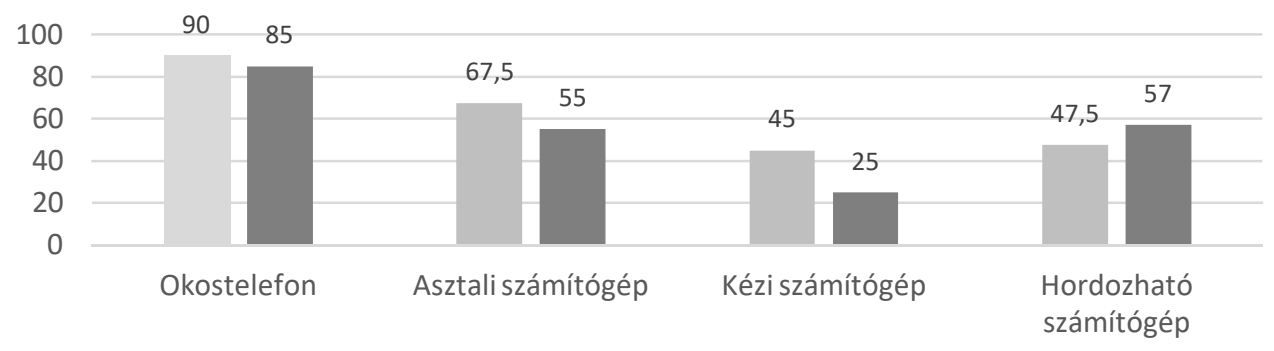

— Vizsgált csoport — Magyar Ifjúság Kutatás 15-19 éves korosztály

Forrás: Magyar Ifjúság Kutatás (2016); saját kutatás

1. ábra: Multimédiás eszközök aránya (\%)

A mobiltelefonnal rendelkezők 68,6 \%-ának készülékéhez mobilinternet szolgáltatás is tartozik. A tanulók 73,6 \%-a okostelefonján, 52,1 \%-a személyi számítógépen, $22,5 \%$-a táblagépen, $20 \%$-a pedig okostévén internetezik. A legtöbben $(50,4 \%)$ egy eszközt használnak internetezés céljából.

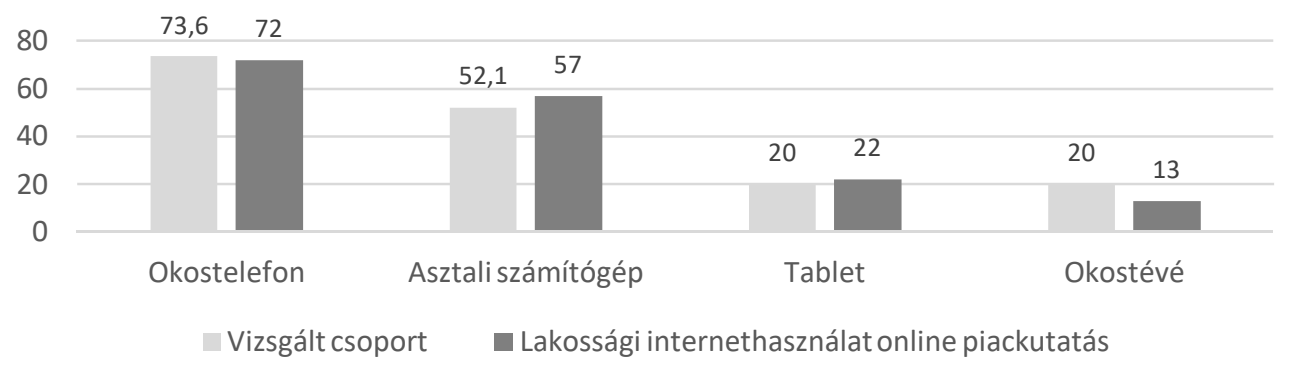

Forrás: NMHH (Nemzeti Média-és Hírközlési Hatóság): Lakossági internethasználat online piackutatás (2017); saját kutatás

2. ábra: Internetezésre használt eszközök aránya (\%)

A kutatásba bevont tanulók sok időt töltenek internetezéssel, 88,2\%-uk naponta csatlakozik a világhálóra, ami magasabb az Eurostat 16-74 évesekre vonatkozó 69\%-os értékénél. Ez természetes, hiszen az internetezők aránya, az életkor 
emelkedésével fordítottan arányosan változik. A három hónapon belüli internethasználók vizsgálatánál, a 16-24 évesek körében már 97,3\%-os értéket közöl az Eurostat, míg a Magyar Ifjúság Kutatás 88\%-ra teszi a 15-29 éves korosztály napi internethasználóinak arányát. Hétköznap a tanulók 78,6\%-a, hétvégén pedig 83,3\%-a tölt több órát napi szinten az interneten. Az NMHH kutatása szerint az internetezés átlagos napi időtartama 3,5 óra. A kutatásban résztvevő tanulók hétköznaponként átlagban több mint 2,5 órát, hétvégén pedig több mint 3 órát töltenek el az online térben.

A kutatásban résztvevő tanulók aktív közösségimédia használónak számítanak, hiszen 95\%-uk regisztrálva van ilyen oldalakon. Országosan jellemző a fiatalok ily nagymértékü részvétele a közösségi médiában, a KSH a 16-24 éves korosztályban szintén 95\%-os arányt mutatott ki.

\begin{tabular}{|c|c|c|}
\hline $\begin{array}{c}\text { Interneten végzett tevé- } \\
\text { kenységek }\end{array}$ & $\begin{array}{c}\text { Közösségi médiahasználat } \\
\text { tevékenységei }\end{array}$ & $\begin{array}{l}\text { Mobiltelefon használat gya- } \\
\text { kori tevékenységei }\end{array}$ \\
\hline $\begin{array}{c}\text { zenehallgatás } \\
75,4 \%\end{array}$ & $\begin{array}{c}\text { chatelés } \\
90 \%\end{array}$ & $\begin{array}{c}\text { zenehallgatás } \\
88,2 \%\end{array}$ \\
\hline $\begin{array}{c}\text { közösségi oldalak látoga- } \\
\text { tása } \\
75 \%\end{array}$ & $\begin{array}{c}\text { kommentelés } \\
82,9 \%\end{array}$ & $\begin{array}{l}\text { telefonálás } \\
89,7 \%\end{array}$ \\
\hline $\begin{array}{c}\text { információ keresés } \\
73,9 \%\end{array}$ & $\begin{array}{c}\text { oldalak követése } \\
75,7 \%\end{array}$ & $\begin{array}{c}\text { fényképezés } \\
85,3 \%\end{array}$ \\
\hline $\begin{array}{c}\text { tanuláshoz való informá- } \\
\text { ciógyüjtés } \\
60 \%\end{array}$ & $\begin{array}{c}\text { képek, videók feltöltése } \\
80,3 \%\end{array}$ & $\begin{array}{c}\text { internetezés } \\
84,2 \%\end{array}$ \\
\hline $\begin{array}{l}\text { internetes játék } \\
53,6 \%\end{array}$ & $\begin{array}{c}\text { híres emberek lájkolása, } \\
\text { követése } \\
69,1 \%\end{array}$ & $\begin{array}{l}\text { játék } \\
83,2 \%\end{array}$ \\
\hline $\begin{array}{c}\text { online vásárlás } \\
37,5 \%\end{array}$ & $\begin{array}{c}\text { csatlakozás csoportokhoz } \\
65 \%\end{array}$ & $\begin{array}{l}\text { videónézés } \\
81,8 \%\end{array}$ \\
\hline \multirow[t]{6}{*}{$\begin{array}{c}\text { fórumok olvasása } \\
11,4 \%\end{array}$} & $\begin{array}{c}\text { csatlakozás eseményekhez } \\
48,9 \%\end{array}$ & $\begin{array}{c}\text { képek küldése } \\
78,2 \%\end{array}$ \\
\hline & $\begin{array}{c}\text { események szervezése } \\
31,8 \%\end{array}$ & $\begin{array}{l}\text { ébresztés } \\
71,5 \%\end{array}$ \\
\hline & & $\begin{array}{c}\text { applikációk letöltése } \\
72,2 \%\end{array}$ \\
\hline & & $\begin{array}{l}\text { sms küldés } \\
72,5 \%\end{array}$ \\
\hline & & $\begin{array}{c}\text { jegyzetkészítés } \\
62,8 \%\end{array}$ \\
\hline & & $\begin{array}{c}\text { rádióhallgatás } \\
33,2 \%\end{array}$ \\
\hline
\end{tabular}

Forrás: saját kutatás

1. táblázat: A multimédiás eszközökön végzett leggyakoribb tevékenységek

A vizsgált tanulók 83,21\%-a naponta látogatja ezeket az oldalakat, 61,1\%-uk naponta többször, 64,3\%-uk pedig naponta egynél több órát tölt el rajtuk. Kutatásom fon- 
tos része volt annak feltárása, hogy a diákok milyen tevékenységeket végeznek mobiltelefonjaikon, az interneten vagy a közösségi oldalakon. A kapott eredményeket egy táblázatban összesítettem. A tanulók legtöbbször folytatott internetes tevékenységei a következők: zenehallgatás $(75,4 \%)$, közösségi oldalak látogatása $(75 \%)$, internetes keresés $(73,9 \%)$. A közösségi oldalak vezető tevékenységei: a chatelés (90\%), a kommentelés (82,9\%), képek, videók feltöltése (80,3\%). A mobiltelefon használat legfontosabb eseményei: zenehallgatás $(88,2 \%)$, telefonálás $(85,7 \%)$, fényképezés $(85,3 \%)$. Az internetet a tanulók átlagosan 8,44, a közösségi oldalakat 8,2, mobiltelefonjaikat pedig 15,9 tevékenységre használják (1. táblázat).

A tanulók otthonában is magas számban találhatóak meg korunk innovatív eszközei.

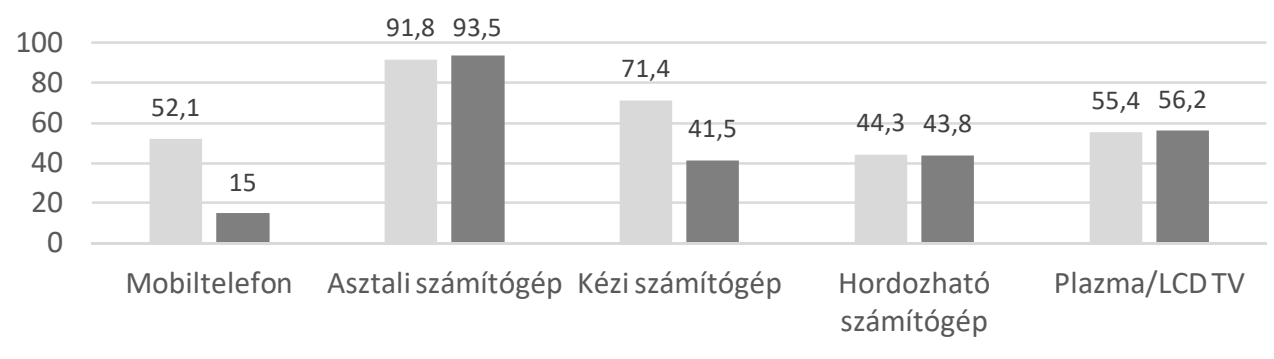

Vizsgált csoport $\quad$ KSH: A háztartások életszínvonala

Forrás: KSH (Központi Statisztikai Hivatal): A háztartások életszínvonala (2017); saját kutatás

3. ábra: Háztartások multimédiás eszközeinek aránya (\%)

Az internet-elérhetőség szempontjából is kedvezö helyzetben vannak a vizsgálatban résztvevő diákok, 88,2\%-uk otthonában ugyanis van internet. A KSH felmérése szerint a magyarországi háztartások 79\%-ának, az Eurostat kutatása szerint 82\%ának van internet-elérhetősége. A Magyar Ifjúság Kutatás szerint, a 15-19 éves korosztályba tartozók háztartásainak internet-hozzáférése $87 \%$-os. Hátrányt csak az internetezésre használt eszközök számában találunk, a négy eszközön internetezők aránya 5,7\%, míg az országos átlag 64\%. A tanulók 55,2\%-a csak egy készüléken tudja elérni a világhálót.

Az NMHH 2017-es kutatásból kiderül, hogy az internetezésre alkalmas kézi eszközök terjedése, a Wi-Fi, a mobilinternet, a közösségi oldalakon való aktív jelenlét, az állandó kapcsolattartás lehetőségének igénye miatt évről évre csökken az otthonukban internetezők tábora. Különösen a fiatalokra igaz ez. A 16-19 éves korosztály 80\%-a az otthonán kívül, más helyeken is internetezik.

A vizsgált tanulók körében a barátoknál való internetezés (53,2\%), illetve az egyéb helyeken történő, világhálóhoz való csatlakozás (43,9\%, rokonoknál, szomszédoknál, ingyenes Wi-Fi elérhetőséggel rendelkező helyeken) a népszerü. Az iskolában 30\%-uk, a könyvtárakban 20\%-uk használja az internetet. Láthatjuk, hogy az elsődleges digitális egyenlőtlenség mentén vizsgálódva a tanulók nincsenek hátrányban, hiszen van lehetőségük a világháló használatára. A különbségek a másod- 
lagos egyenlőtlenség mentén rajzolódnak ki, mivel az internetelérés lehetősége nem mindenki számára egyformán biztosított. Vannak, akik bárhol és vannak, akik csak bizonyos helyeken, például otthon, iskolában, ingyenes Wi-Fi elérhetőségnél vagy teleházakban tudnak csak belépni az online térbe. Ez utóbbiakat hátrányos helyzetü településeken hozták létre, modern multimédiás eszközökkel felszerelve, a digitális szakadék felszámolásának érdekében. A tanulók 6,1\%-a él ezzel a lehetőséggel. Az alacsony szám arra is utalhat, hogy a többségnek nincs rá szüksége, hogy igénybe vegye ezt a szolgáltatást, mert máshol is megvan a lehetősége az internetezésre. Ugyanilyen fontos az autonómia, hogy mennyire szabadon használhatja az adott egyén az internet nyújtotta lehetőségeket. Ebben az esetben a tanulók számára a kontrollt elsősorban a szülö és az iskola jelenti. Vannak olyan intézmények, amelyekbe mobiltelefont sem lehet bevinni. A válaszokból kiderült, hogy szülői kontroll, az interneten folytatott tevékenységek során, ha van is, csak időszakos. A szülőkkel történő gyakori, közös internetezés a tanulók csupán 23,2\%-ára igaz. Amikor egyedül használják a világhálót, 78,2\%-uk mellé soha, vagy csak nagyon ritkán ül oda a szülö. A szülők 66,9\%-a ritkán vagy sohasem beszél gyermekeivel az interneten látott tartalmakról. Időkorlát valószínüleg a legtöbb tanuló esetében elöfordul, de mivel a tanulók sok időt töltenek hétköznap és hétvégén is az interneten, valószínü, hogy nem túl szigorúak a szülők e tekintetben, inkább a büntetésből való használatmegvonás lehetőségét alkalmazzák. A szülők 63,3\%-a él ezzel a lehetőséggel. A másodlagos egyenlőtlenség harmadik dimenziójához tartozik a társadalmi támogatás mértéke, tehát abban az esetben, ha nehézségbe ütközik a tanuló, akkor kihez fordulhat segítségért. Úgy tünik a Beregben élő szülők segítségnyújtása nem számottevő. A legkevesebbszer abban segítenek a szülők, hogy gyermekeik jobban ki tudják használni az internet nyújtotta lehetőségeket (a „soha” válaszok aránya 51,8\% volt) A biztonsági beállításokban, szürők használatában (a „soha” válaszok aránya 50,7 \% volt) szintén nem kapnak elég támogatást a tanulók. A legtöbb segítséget a szülök az oldalak tartalmának elmagyarázásában, a böngészésben és az online világban szerzett negatív tapasztalatok feldolgozásában nyújtották.

\section{A kutatás eredményei}

Kutatásom első kérdéskörét a multimédiás és IKT-eszközökkel való ellátottság szociodemográfiai és szocioökonómiai hátterének vizsgálata adta. Elsőként arra kerestem a választ, hogy a szülők iskolai végzettsége befolyással van-e a tanulók multimédiás eszközeinek számára és azok használatának változatosságára. A válasz egyértelmüen igen. A saját és az otthoni multimédiás, valamint az internetezésre használt eszközök száma arányosan növekszik a szülök iskolai végzettségével. A két tényező között közepes hatáserősségü, szignifikáns összefüggés található a Spearman-féle rangkorrelációs vizsgálat szerint (saját multimédiás eszközök száma - apa: $\mathrm{p}<0,000$, rho $=0,325$, anya: $\mathrm{p}<0,000$, rho $=0,405$; otthoni multimédiás eszközök száma - apa: $\mathrm{p}<0,000$, rho $=0,375$, anya: $\mathrm{p}<0,000$, rho $=0,462$ internetezésre használt eszközök száma - apa: $\mathrm{p}<0,002$, rho $=0,184$, anya: $\mathrm{p}<0,001$, rho $=0,201$.) Az okostelefonok birtoklásával kapcsolatban már csak az anyák iskolai végzettsége 
mutat összefüggést, kereszttábla elemzést végezve $(p<0,012$, Cramer $V=0,216)$. A további elemzések végzéséhez létrehoztam egy vulnerabilitás mutatót, melyhez a szülök legmagasabb befejezett iskolai végzettségére vonatkozó változókat vettem figyelembe oly módon, hogy abba mindkét szülő végzettsége egyformán beleszámítson. A szülők végzettségének megadására 5 opció ált a tanulók rendelkezésére, így a két szülőt együtt vizsgálva egy 2-10-ig terjedő értékekkel rendelkező változót kaptam, mely esetében a 2 és 4 közötti értékek az alacsony, míg az 5 és 10 közötti értékek a magas végzettségi kategóriát jelölik. Ezeket az értéktartományokat összevonva jött létre a dichotóm vulnerabilitás mutató (melynek 1-es értéke jelöli a szülők alacsony végzettségét, vagyis a sérülékenységet, míg 0 értéke a szülők magas végzettségét). A vulnerábilis csoportba a vizsgált minta (59\%-a), míg a nem vulnerábilis csoportba 41\%-a tartozott. A két csoport digitális eszközökkel való ellátottságát hasonlítottam össze. 5 változót hoztam létre (saját multimédiás eszközök száma, otthoni multimédiás eszközök száma, internethasználat változatossága, internetezésre használt eszközök száma, szülöi segítségnyújtás), melyeket egytényezős varianciaanalízissel vizsgáltam meg. Ez, a Spearman- féle rangkorrelációs elemzés eredményeivel összhangban kimutatta, a saját multimédiás eszközök ( $p=0,000)$, az otthoni multimédiás eszközök $(p=0,000)$ és az internetezésre használt eszközök $(p=0,003)$ számánál a szignifikáns különbséget a két csoport között.

\begin{tabular}{ccccc}
\hline & Szignifikancia & F érték & \multicolumn{2}{c}{ Átlag } \\
\cline { 4 - 5 } & & 5 Vevésbé & $\begin{array}{c}\text { Inkább } \\
\text { vulnerábilis }\end{array}$ \\
\hline $\begin{array}{c}\text { Saját multimédiás eszközök } \\
\text { száma }\end{array}$ & 0,000 & 59,324 & 9,06 & 5,46 \\
\hline $\begin{array}{c}\text { Otthoni multimédiás } \\
\text { eszközök száma }\end{array}$ & 0,000 & 46,073 & 10,17 & 6,75 \\
\hline Világhálóhasználat & 0,004 & 8,477 & 9,34 & 7,88 \\
\hline $\begin{array}{c}\text { Internetezésre használt } \\
\text { eszközök száma }\end{array}$ & 0,003 & 9,250 & 1,92 & 1,57 \\
\hline
\end{tabular}

Forrás: saját kutatás

2. táblázat: A vulnerabilitás összefüggései a digitális eszközökkel való ellátottsággal, illetve azok használatának változatosságával

Az újabb két változó (okostelefon, mobilinternet) használatával végzett kereszttábla elemzés tovább árnyalta a képet. A vulnerabilitás és a saját okostelefonnal való rendelkezés között szignifikáns $(\mathrm{p}=0,005)$, de gyenge szorosságú kapcsolat van (Cramer $\mathrm{V}=0,169)$. A mobilinternettel való rendelkezés esetén már csak marginálisan szignifikáns - vagyis 10\%-os szignifikancia szinten értelmezhető - összefüggést találunk $(\mathrm{p}=0,059)$, a két változó közötti kapcsolat pedig ez esetben is gyenge (Cramer $\mathrm{V}=0,114)$. Nem csak a multimédiás eszközök számával, hanem használatukkal kapcsolatban is sikerült összefüggéseket feltárni. Az internethasználat változatossága pozitív irányban korrelál mindkét szülő iskolai végzettségével (apa: $\mathrm{p}<0,029$, rho=0,132, anya: $\mathrm{p}<0,000$, $\mathrm{rho}=0,218$ ). Ezt az eredményt az inkább vulnerábilis és a kevésbé vulnerábilis csoport varianciaanalízises vizsgálata is megállapította $(\mathrm{p}=0,004)$. Az okostelefonok használatának változatosságával kapcsolat- 
ban megállapítást nyert, hogy az apák iskolai végzettségének van szignifikáns $(\mathrm{p}=0,035)$, de csak kis mértékü $\left(\right.$ eta $\left.^{2}=0,041\right)$ hatása. A vulnerábilis és nem vulnerábilis csoportok kereszttábla elemzése pedig azt mutatta, hogy a mintában az alacsonyabb végzettségü szülők gyermekei használták nagyobb arányban (58\%) mobiltelefonjukat internetezésre. Ez a kapcsolat azonban nem volt szignifikáns. A szülöi segítségnyújtásban lehet még felfedezni kapcsolatot az apa végzettségére vonatkozóan $(\mathrm{p}<0,028$, rho: 0,140$)$. Ezt az összefüggést a vulnerábilis és nem vulnerábilis csoportot összehasonlító vizsgálat nem igazolta $(\mathrm{p}=0,301)$. Általánosságban igaz tehát, hogy a magasabb végzetségü szülők gyermekei több multimédiás eszközzel rendelkeznek, ám ha a korosztály legmodernebb, leginnovatívabb eszközét, azaz az okostelefont, valamint a hozzá kapcsolódó mobilinternetet nézzük, akkor már ez az állítás nem állja meg a helyét. Az okostelefonok használatával kapcsolatban is igaz ez, hiszen használatának változatosságára csak az apa végzettsége gyakorol hatást. Továbbra is kimutatható viszont az internethasználat és a szülők iskolai végzettsége között fennálló kapcsolat. A kereszttábla elemzés szerint az internethasználat gyakoriságára ellenben már nincs befolyással a szülők végzettsége.

Két egyváltozós logisztikus, regressziós modell felállítására is sor került. Ezek magyarázó változóját a vulnerabilitás változó, függő változóját pedig az egyiknél a saját multimédiás eszközök számát jelző változó, a másiknál az otthoni multimédiás eszközök számát jelző változó adta. Ezek szintén dichotóm vagyis kétértékü változók, ahol a 0 érték a kevés, míg az 1-es érték a sok multimédiás eszközzel való rendelkezést jelöli. A saját multimédiás eszközökre vonatkozó modell magyarázó ereje a Nagelkerke $\mathrm{R}^{2}$ alapján 0,152 volt, az otthoni multimédiás eszközökre vonatkozó modellé 0,172 . Azt láthatjuk, hogy a vulnerabilitás szignifikánsan (mindkét modellnél $\mathrm{p}=0,000)$ jelzi elöre a saját $(B=-1,460)$ és az otthoni $(B=-1,574)$ multimédiás eszközökkel való ellátottságot.

A kapott eredményekből azt a következtetést tudom levonni, hogy a szülők iskolai végzettsége ugyan még mindig hatással van a digitális eszközök meglétére, a világháló használatára, de szerepe egyre inkább csökkenő tendenciát mutat. Az látszik, hogy mai társadalmunkban, anyagi helyzettől és végzettségtől függetlenül, alapvető szükségletként jelenik meg a digitális technológia.

A szegénység és társadalmi kirekesztődés kockázati tényezői között a kor, a nem és az iskolai végzettség mellett a háztartások anyagi helyzete is kulcsfontosságú tényező. Ezért ennek összefüggéseit is vizsgáltam a multimédiás eszközök számára és használatának változatosságára vetítve. A Spearman-féle rangkorrelációs, a Pearson-féle korrelációs vizsgálat és a két mintás t próba a következő eredményeket hozta. Mind a saját, mind az otthoni multimédiás eszközszám több az anyagi helyzetet éríntő tényezővel korrelál. Úgy, mint a pénzkeresők száma (saját: $p<0,011$, rho: 0,152, otthoni: $p<0,005$, rho $=0,170$ ), a család anyagi helyzete (saját: $p<0,000$, rho: 0,259, otthoni: $p<0,000$, rho=0,277), a jövedelmi helyzet (saját: $p<0,003$, rho $=0,179$, otthoni: $\mathrm{p}<0,004$, rho $=0,173$ ) vagy a munkanélküliség hiánya a családban (saját: $\mathrm{t}=2,355, \mathrm{p}=0,019$, otthoni: $\mathrm{t}=2,652, \mathrm{p}=0,008$ ). Ezeken kívül az internethasználat eszközeinek számánál is találunk szignifikáns kapcsolatot az anyagi helyzettel $(p<0,002, r h o=0,139)$ és a jövedelmi helyzettel $(p<0,007$, rho=0,160) összefüggésben. Szintén felfedezhető kapcsolat a saját és az otthoni multimédiás eszközök, valamint az internetezésre használt berendezések száma és az anyagi helyzet szubjek- 
tív megítélésének összevetésekor (saját: $\mathrm{p}<0,000, \mathrm{r}=0,371$, otthoni: $\mathrm{p}<0,000$, $\mathrm{r}=0,311$, internetezésre használt: $\mathrm{p}<0,008, \mathrm{r}=0,161)$. A család létszáma és a tanulók multimédiás eszközeinek száma között fordított arányosság mutatható ki $(\mathrm{p}<0,041$, rho=-0,122). A család létszáma és a család anyagi, jövedelmi helyzete vagy a pénzkeresők száma között ez a kutatás nem mutatott ki szignifikáns összefüggést. Az eszközök számával kapcsolatban viszont talált kapcsolatot. Azok a tanulók használják többet az internetet, akik gazdagabbnak érzik magukat $(\mathrm{p}<0,000, \mathrm{r}=0,263)$, ahol több a pénzkereső családban $(\mathrm{p}<0,016$, rho=0,145) és ahol a család magasabb jövedelmi $(\mathrm{p}<0,032, \mathrm{rho}=0,128)$ és anyagi státusszal rendelkezik $(\mathrm{p}<0,007$, rho=0,162). A világháló otthonon kívüli használata már csak a pénzkeresők számával hozható összefügésbe $(\mathrm{p}<0,020, \mathrm{rho}=0,139)$. A mobilhasználat változatossága korrelál a családok jövedelmi $(p<0,000$, rho=0,265) és anyagi helyzetével $(p<0,006$, rho=0,176), valamint a diákok szubjektív jólétének megítélésével $(\mathrm{p}<0,001, \mathrm{r}=0,210)$.

A szegénységről alkotott, hagyományos kép átalakulását bizonyítja kutatásom is. A 21. században már nem számít luxusnak a multimédiás eszközök birtoklása. Megállapítom, hogy az anyagi helyzet továbbra is hatással van a digitális eszközökkel való ellátottságra, azonban nem ez az elsődleges oka a digitális egyenlőtlenségnek. Így feltehetően a célzott anyagi támogatásokkal (mint például laptopok, tabletek pályázati lehetőségei) a mélyszegénységben élők felzárkózását lehet elősegíteni. A tanulók többsége azonban vélhetően ilyen jellegü támogatás nélkül is megszerzi a vágyott multimédiás eszközt. Más kérdés persze, hogy ez az eszköz milyen minőségü, a legkorszerübb vagy a kifutó félben lévők közül való, valamint, hogy mennyire tudja azt használni a tanuló, milyen fokú a digitális kompetenciája.

Kutatásomban a multimédiás eszközök számát és használatát a lakóhely minőségének tükrében is vizsgáltam. A Pearson-féle korrelációs elemzés talált is összefüggést a saját $(\mathrm{p}<0,016, \mathrm{r}=-0,145)$, az otthoni $(\mathrm{p}<0,008, \mathrm{r}=-0,161)$ multimédiás eszközök számával, az internethasználattal $(\mathrm{p}<0,039, \mathrm{r}=-0,125)$ és az otthonon kívüli internetezéssel $(\mathrm{p}<0,009, \mathrm{r}=-0,158)$ kapcsolatban és mint azt feltételeztem, mindezt negatív előjellel. Itt is szembetünő, hogy nincs kapcsolat az okostelefonok számával vagy azok használatának változatosságával, a közösségi médiahasználattal, de még az internetezésre használt eszközök számával sem. A diszkriminancia vizsgálat egy szignifikáns kapcsolatot tárt fel az internetezés hosszát illetően $(p<0,004$, Wilks' Lambda érték: 0,935). A problémásabb környéken élök több időt szánnak internetezésre a jobb környéken élő társaikhoz képest.

A feltárt, kis mértékü kapcsolatokat annak tulajdonítom, hogy az ilyen környéken élők általában rosszabb anyagi körülmények között kell, hogy boldoguljanak. A kistérség szegregátumaiban, gettósodott városrészeiben, ahol magas az alapszükségletek hiánya, ugyanúgy megtalálhatóak a legnépszerübb multimédiás eszközök például az okostelefon vagy az okostelevízió.

Végezetül dolgozatom első kérdéskörében kitértem a fiúk és lányok médiahasználati jellemzőire is. Az átlagszámításokból az olvasható le, hogy a fiúk több saját tulajdonú (fiúk: 7,55 db, lányok: 5,96 db), és több otthoni multimédiás eszközzel (fiúk: 8,51 db, lányok: 7,53) rendelkeznek, az internetet több eszközön használják (fiúk: 1,77 db, lányok: 1,6 db), több mindenre (fiúk: 8,51 tevékenység, lányok: 8,35 tevékenység) és otthonukon kívül több helyen interneteznek (fiúk:1,21 helyszín, 
lányok:1,17 helyszín). A lányok ezzel szemben a közösségi média több lehetőségét használják ki (lányok: 8,58 tevékenység, fiúk: 8,02 tevékenység), ahogyan mobiltelefonjaikat is több funkcióra használják (lányok:16,65 funkció, fiúk: 15,47 funkció), több szülői segítséget kapnak (lányok: 5,43 tevékenység esetében, fiúk: 4,42 tevékenység esetében) és irányukban magasabb a szülöi felügyeletet (lányok: 4,42 tevékenység, fiúk: 3,41 tevékenység) is. Azonban a különbségek a legtöbb esetben minimálisak, három esetben érik el a szükséges szignifikancia szintet (saját multimédiás eszközszám: $\mathrm{t}=3,319, \mathrm{p}=0,002$; mobiltelefon használat: $\mathrm{t}=-2,237, \mathrm{p}=0,026$, szülöi segítségnyújtás mértéke: $\mathrm{t}=-2,671, \mathrm{p}=0,008)$. Tehát a beregi kistérségben a két nem közötti, számottevő különbségek csak ezen három tényező mentén mutathatók ki. A fiúk magasabb multimédiás eszközszáma abból adódhat, hogy általában jobban vonzódnak az innovatív technikai eszközökhöz, míg a lányok kicsivel változatosabb mobiltelefonhasználata az eltérő közösségi médiahasználati szokásokból eredeztethető. Az pedig, hogy a szülők nagyobb mértékü segítséget nyújtanak lányaik számára abból adódhat, hogy jobban féltik őket az online világ veszélyeitől, valamint, hogy technikai tudásuk a legtöbbször még elmarad a fiúkétól.

\section{Záró gondolatok}

A beregi kistérség Magyarország egyik legelmaradottabb kistérsége, ahol gyakorlatilag az összes ,hagyományosnak” tekinthető társadalmi kirekesztődést eredményező tényező megfigyelhető, a tanulók fokozottan ki vannak téve az elszegényedés kockázatának. Azonban digitális világunkban mindezek mellett egy újabb tényezővel is számolnunk kell. Ez pedig a digitális analfabetizmus, mely azon személyeket takarja, akik nem tudják az innovatív eszközöket oly mértékben használni, hogy ezáltal életminőségük javuljon, vagy legalább stagnáljon. Ahogyan kockázatot jelent az internetezésre használt multimédiás eszközök hiánya is, hiszen így az egyénnek lehetősége sincsen a megfelelő színtü jártasság megszerzésére. Az információs társadalom korában a modern eszközök használata nem választás kérdése. Aki kivonja magát a használatuk alól, elkerülhetetlenül hátrányba kerül a digitálisan képzettebb társaival szemben. Lassabban, nehezebben éri el a különböző szolgáltatásokat, jelentősen csökkennek esélyei a munkavállalásra vagy a magasabb fizetésre, társadalmi beilleszkedése nehézkesebbé válik.

A kérdés fontosságával a kormány is tisztában van, hiszen a Digitális Oktatási Stratégia felhívja a figyelmet a digitális kompetenciákban jelentkező különbségek (szociális helyzet, társadalomföldrajzi elhelyezkedés) társadalmi egyenlőtlenséget növelő hatására. A digitális esélyteremtés megvalósulásában az oktatásnak és a képzésnek tulajdonítják a legnagyobb szerepet. A program célja, hogy senki ne hagyhassa el az oktatást a szükséges digitális kompetenciák elsajátítása nélkül. Az esélyegyenlőség megteremtése az állam, valamint az oktatási intézmények számára is fontos feladat. A digitális kirekesztődés kockázatára nézve ez azt jelenti, hogy minden diák számára elérhetők kell, hogy legyenek ugyanazok az innovatív eszközök. Meg kell teremteni a lehetőségét, hogy azok használatának elsajátításában se kerüljenek hátrányba a társadalom leszakadó rétegei. Mindennek elsődleges színtere az 
iskola kellene, hogy legyen. A kutatás eredményei arra világítanak rá, hogy olyan programok lehetnek eredményesek, melyek a másodlagos digitális megosztottság felszámolását célozzák meg. A másodlagos digitális megosztottság elleni küzdelem azonban csak az elsődleges megosztottság eltüntetésével lehet hatékony. Ennek megteremtése érdekében állami vagy települési szinten átgondolandó lehetőség lehetne az ingyenes internethozzáférés biztosítása az oktatásban részt vevők számára, felújított számítógépek, multimédiás eszközök tartós használatba adása. Továbbá a DOS fontos eleme a tanulók saját eszközeinek bevonása a tanítás-tanulás folyamatába. Erre ma még kevés példát láthatunk. Kutatásommal célom volt annak kiderítése, hogy a beregi kistérség diákjai milyen mértékben vannak birtokában a szükséges eszközöknek. Kevés kivételtől eltekintve azt kell mondanom, hogy megfelelö mértékben. Az iskolák és a tanulók eszközellátottsága is megfelel az országos átlagnak, és ha nem is a leginnovatívabb eszközökkel rendelkeznek, a lemaradás nem olyan mértékü, amely lehetetlenné tenné a digitális oktatás szélesebb körü kiterjesztését.

A kistérség településeinek problémái összetettek, de alapját a munkalehetőségek tartós hiánya miatt kialakuló szegénység jelenti. Ezért a kistérség felzárkózásának, az itt élö emberek életszínvonalának emelése szempontjából legfontosabb tényező az aktív korúak minél nagyobb részének elhelyezkedése a munka világában. Ezzel csökkenthető legnagyobb mértékben a szegénység és társadalmi kirekesztődés. A magyar állam is arra próbálja ösztönözni a munkaképes embereket, hogy a szociális ellátórendszer igénybevétele, a közmunkaprogramokban való részvétel helyett, az elsődleges munkaerőpiac aktív részeseivé váljanak.

Egyre csökken a szakképzettség nélkül végezhető, betanított munkahelyek száma országunkban, az igény az informatikai, robotikai képzettségü szakemberek iránt viszont évröl évre növekszik. A digitális társadalom korában a digitális eszközöket müködtetni tudó, hozzáértő szakemberekre van szükség, akik képzése nem szabhat gátat a kistérség társadalmi felzárkózásának. A digitális egyenlőtlenségek a már meglévő társadalmi egyenlőtlenségekhez adódnak hozzá és tovább mélyítik azokat. Ha a vásárosnaményi és a hozzá hasonlóan hátrányos helyzetben lévő kistérségekben a kormány hagyja elmélyülni a digitális egyenlőtlenségeket, azzal elveszi az esélyt az itt élők felzárkózása elől.

\section{Irodalomjegyzék}

1. Balázs Gábor - Habarics Anikó - Nagy Gábor - Czaller László - Kulcsár Gábor - Luksander Alexandra (2012): Vásárosnaményi kistérségi tükör. Helyzetfeltárás, TÁMOP 5.2.1-11/1. Budapest, Magyar Máltai Szeretetszolgálat. 112.

2. https://gyerekesely.tk.mta.hu/uploads/files/kistersegi tukor_vasarosnameny.pdf

3. Bodonyi Edit - Hegedüs Judit - Fekete Márta (2015): Korai iskolaelhagyás kriminalitás - megoldási lehetőségek az oktatás szemszögéből, In: Lancaric Daniel [ed], Jazykovedné, Literárnovedné a didaktické kolokvium XXXII. Pozsony, Z-F LINGUA, 22-33. 
4. Csepeli György - Prazsák Gergő (2010): Internet és társadalmi egyenlőtlenségek Magyarországon. In: XXI. Század - Tudományos Közlemények. Budapest, Általános Vállalkozási Főiskola, 7-21.

5. Csepeli György - Prazsák Gábor (2012): Információs társadalom 2.0. In „Információs társadalom 2.0.” Előadás, Budapest, Eötvös Loránd Tudományegyetem.

6. Fábián Gergely - Takács Péter (2012): A jövedelmi egyenlőtlenségek változásai és a szegénység. Acta medicinae et sociologica (3), 3: 33-48.

7. Galácz Anna - Ságvári Bence (2008): Digitális döntések és másodlagos egyenlőtlenségek: a digitális megosztottság új koncepciói szerinti vizsgálat Magyarországon. Információs Társadalom (8), 2: 37-52.

8. Hargittai Eszter (2003): How Wide a Web: Inequalities in Access to Information Online. Ph.D. Sociology. New Jersey, Princeton University.

9. Spéder Zsolt (2002): A szegénység változó arcai. Tények és értelmezések: Tények és értelmezések. Budapest, Századvég kiadó.

10. Spéder Zsolt (2003): Gyermeket vállalni - új strukturális körülmények között Család és népesség - itthon és Európában, In: Spéder Zsolt (szerk.), Család és népesség - itthon és Európában. Budapest, KSH Népességtudományi Kutatóintézet, Századvég kiadó. 86-112.

11. Székely Levente (2018): Magyar fiatalok a Kárpát-medencében: Magyar Ifjúság Kutatás 2016. Budapest, Kutatópont Kft., Enigma 2001 Kiadó és Médiaszolgáltató Kft.

12. Európai Bizottság (2001): Social Eclusion: Comission Takes First Step

Towards EU Powerty Strategy.

http://europa.eu.int/comm/employment social/news/2001/oct/iO11395 en.html.

13. KSH: A háztartások életszínvonala, 2017. https://www.ksh.hu/docs/hun/xftp/idoszaki/hazteletszinv/hazteletszinv17.pdf.

14. KSH: Az infokommunikációs technológiák és szolgáltatások helyzete Magyarországon, 2016.

15. https://www.ksh.hu/docs/hun/xftp/idoszaki/ikt/ikt16.pdf.

16. Magyar Ifjúság Kutatás 2016. Az ifjúságkutatás első eredményei. Ezek a mai magyar fiatalok! Székely Levente- Szabó Andrea (szerk.), Társadalomkutató Kft.

17. http://www.ujnemzedek.hu/sites/default/files/magyar_ifjusag_2016 a4 web.pdf.

18. NMHH: Lakossági internethasználat online piackutatás 2017. http://nmhh.hu/dokumentum/195102/lakossagi_internethasznalat_2017.pdf.

19. NMHH: Lakossági internethasználat online piackutatás 2016.

20. http://nmhh.hu/dokumentum/187704/lakossagi internethasznalat 2016.pdf.

21. Magyarország Digitális Stratégiája (2016) Budapest,

22. http://www.kormany.hu/download/0/cc/d0000/MDO.pdf. 